Teknik, 37 (2), 2016, 78-83

\title{
Penyisihan Limbah Organik Air Lindi TPA Jatibarang Menggunakan Koagulasi-Flokulasi Kimia
}

\author{
Arya Rezagama ${ }^{*}$ Mochtar Hadiwidodo, P. Purwono, Nurul Fajri Ramadhani, Mia Yustika \\ Departemen Teknik Lingkungan, Fakultas Teknik, Universitas Diponegoro, \\ Jl. Prof. Soedarto, SH, Kampus Undip Tembalang, Semarang, Indonesia 50275
}

\begin{abstract}
Abstrak
Air lindi yang meresap ke dalam tanah yang berpotensi bercampur dengan air tanah sehingga menimbulkan pencemaran tanah, air tanah dan air permukaan. Komposisi limbah lindi dari berbagai TPA berbeda-beda bergantung pada musim, jenis limbah, umur TPA. Proses dalam TPA menghasilkan molekul organik recalcitrant yang ditunjukkan dengan rendahnya rasio BOD/COD dan tingginya nilai $\mathrm{NH}_{3}-\mathrm{N}$. Belum optimalnya pengolahan air lindi di Jatibarang membutuhkan pretreatment sebagai bentuk upaya alternatif dalam proses pengolahan air lindi sebelum masuk ke dalam proses aerated lagun. Penelitian ini bertujuan untuk menganalisa pengaruh koagulan kimia pada penyisihan bahan organik air lindi TPA Jatibarang. Penelitian dilakukan pada bulan AprilAgustus 2016. Karaktersitik air lindi TPA Jatibarang termasuk dalam kategori "moderately stable"

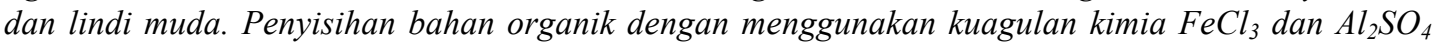
menunjukkan nilai yang cukup signifikan untuk parameter COD, BOD, TSS. Penggunaan dosis optimal terjadi pada $16 \mathrm{~g} / \mathrm{L} \mathrm{FeCl}_{3}$ serta $16 \mathrm{~g} / \mathrm{L} \mathrm{Al}_{2} \mathrm{SO}_{4}$ dapat menurunkan nilai COD sebesar $51 \%$ dan 65\%, BOD sebesar 50\% dan 56\%, dan TSS sebesar 24\% dan 21\%. Perubahan nilai pH akibat penambahan koagulan berpengaruh positif terhadap tingkat penyisihan, namun memberikan dampak negatif yaitu buih yang cukup banyak. Penurunan beban organik menguntungkan bagi sistem pengolahan lindi eksisting TPA Jatibarang.
\end{abstract}

Kata Kunci: Bahan Organik; Lindi; Koagulasi-flokulasi

\begin{abstract}
[Title: Removal of Lindi Water Organic Waste of TPA Jatibarang using Chemical CoagulationFloculation] Leachate grounding into the soil that potentially could mix with the groundwater caused contamination of soil, groundwater and surface water. The composition of waste landfill leachate from the various location is depending on the season, the type of waste, and landfill age. Process in the TPA produces recalcitrant organic molecules as indicated by the low ratio of BOD/COD and $\mathrm{NH}_{3}-\mathrm{N}$ high value. The ineffective treatment of leachate at Jatibarang require a pretreatment as a form of alternative effort in the processing of leachate prior to entry into the aerated lagoon process. This study aims to analyze the influence of chemical coagulants on grounding organic material Jatibarang landfill leachate. The study was conducted in April-August 2016. Jatibarang landfill leachate characteristics were categorized as "moderately stable" and young leachate. Allowance for organic materials using chemical coagulants of $\mathrm{FeCl}_{3}$ and $\mathrm{Al}_{2} \mathrm{SO}_{4}$ showed significant values for the parameters of COD, BOD, and TSS. The use of optimal dose occurs at $16 \mathrm{~g} / \mathrm{L} \mathrm{FeCl}$ and $16 \mathrm{~g} / \mathrm{L}$ $\mathrm{Al}_{2} \mathrm{SO}_{4}$ which can reduce the COD value by $51 \%$ and $65 \%$, BOD by $50 \%$ and $56 \%$, and TSS at $24 \%$ and $21 \%$. PH value changes due to the addition of coagulant positive effect on the level of the allowance, but a negative effect that is quite a lot of froth. The decline in organic load favorable for existing landfill leachate treatment systems Jatibarang.
\end{abstract}

Keyword: Organic Materials; Lindi; Coagulation-floculation

\section{Pendahuluan}

Air lindi yang meresap ke dalam tanah yang berpotensi bercampur dengan air tanah sehingga menimbulkan pencemaran tanah, air tanah dan air permukaan. Hingga kini sebagian besar TPA di indonesia masih belum mampu mengolah outlet air lindi sesuai standar baku mutu buangannya. Lindi

\footnotetext{
* Penulis Korespondensi

E-mail: arya_tl@ft.undip.ac.id
}

tergolong sulit dalam pengolahan limbah secara proses biologi. Komposisi limbah lindi dari berbagai TPA berbeda-beda bergantung pada musim, jenis limbah, umur TPA. Proses dalam TPA menghasilkan molekul organik recalcitrant yang ditunjukkan dengan rendahnya rasio BOD/COD dan tingginya nilai $\mathrm{NH}_{3}-\mathrm{N}$ (Renoua dkk., 2005).

Sedangkan kuantitas lindi bergantung pada jumlah masuknya air dari luar, terutama air hujan, disamping dipengaruhi oleh aspek operasional yang diterapkan seperti aplikasi tanah penutup, kemiringan 
Teknik, 37 (2), 2016, 79

permukaan, kondisi iklim, dan sebagainya sehingga kuantitasnya bervariasi dan fluktuatif (Englehardt, 2006). Penelitian lain menunjukkan tanaman padi yang disirami dengan air lindi dapat mengakibatkan bulir padi mengandung logam berat cukup tinggi sebesar $(766,80 \mathrm{mg} / \mathrm{kg})$ sehingga berbahaya untuk dikonsumsi (Ali, 2011).

Tempat Pemrosesan Akhir (TPA) Jatibarang menampung pembuangan sampah se-Kota Semarang. Besarnya volume sampah yang masuk dan curah hujan yang tinggi di daerah tropsis berpotensi menghasilkan air lindi dalam jumlah yang besar. Kondisi eksisting unit pengolahan berupa kolam stabilisasi belum menghasilkan kualitas efluen sesuai dengan baku mutu. Nilai BOD/COD yang rendah membuat pengolahan secara biologi biasa sulit dilakukan (Rezagama \& Notodarmojo, 2012). Secara visual nampak bahwa warna air lindi pada saluran inlet tidak jauh berbeda dengan outletnya.

Belum optimalnya pengolahan air lindi di Jatibarang membutuhkan pretreatment sebagai bentuk upaya alternatif dalam proses pengolahan air lindi sebelum masuk ke dalam proses aerated lagun. Pengolahan secara koagulasi flokulasi, adsorpsi ini dapat meningkatkan keberhasilan proses biologi pada kolam anaerob IPAL eksisting. Pretreatment yang dimaksudkan adalah dengan menerapkan proses koagulasi flokulasi dalam menurunkan beban organik air lindi serta menyisihkan padatan tersuspensi sehingga pengolahan selanjutnya lebih mudah.

Proses koagulasi akan membuat partikel halus yang tidak dapat diendapkan secara gravitasi biasa, menjadi partikel yang lebih besar (mikro flok) dengan cara pengaduan cepat. Kemudian dilanjutkan flokuasi pengadukan pelan untuk membentuk flok yang lebih besar. Disamping itu koagulasi berguna untuk memudahkan partikel-partikel tersuspensi dan bahan koloid yang terlarut menjadi agregat sebagai tahapan proses sebeum penggumpalan yang akhirnya membentuk flok. Sehingga dapat dipisahkan dengan proses pengendapan dan disamping itu berfungsi menghilangkan beberapa jenis organisme (pathogen) dalam air (Tjokrokusumo, 1995). Proses koagulasi flokulasi sebagai pretreatment dapat menghilangkan secara efektif bahan recalsitrant dalam lindi dan mengurangi beban polutan yang mempengaruhi proses bologi. $\mathrm{FeCl}_{3}$ dapat meningkatkan biodegradabel air lindi (Liu dkk., 2012).

Penelitian terdahulu koagulasi dan flokulasi sebagai pretreatment menunjukkan hasil yang cukup baik (Liu dkk., 2012; Li dkk., 2010; Mavros dkk., 2008). Namun penelitian tersebut banyak di terapkan pada negara maju dengan kondisi Tempat Pengolahan Akhir yang sudah menerapkan sanitary landfill dengan baik. Kondisi di TPA Jatibarang memiliki karakteristik yang berbeda akibat sistem yang digunakan belum sanitary landfill sepenuhnya serta. Hal ini mungkin mengakibatkan beban organik yang muncul lebih besar dengan debit yang berfluktuasi. Secara rinci tujuan penelitian ini ialah menganalisa pengaruh koagulan kimia penyisihan bahan organik air lindi TPA Jatibarang serta berapa komposisi optimal koagulan kimia yang digunakan untuk mengolah lindi TPA Jatibarang.

\section{Metode Penelitian}

Penelitian ini dilakukan pada bulan AprilAgustus 2016. TPA Jatibarang berlokasi di Kelurahan Kedungpane, Kecamatan Mijen, Kota Semarang yang memiliki luas sekitar $46 \mathrm{Ha}$, dan menerima 800 ton limbah padat domestik per hari. Sampel air lindi TPA Jatibarang yang digunakan dalam penelitian ini diambil dari saluran inlet instlaasi pengolahan TPA Jatibarang. Pengambilan sampel air lindi pada Instalasi Pengolahan Limbah (IPL) TPA Jatibarang menggunakan metode grab sampling sesuai dengan SNI 6989.59:2008 tentang Metode Pengambilan Contoh Air Limbah. Pengambilan sampel air lindi IPL TPA Jatibarang menggunakan sebuah jerigen plastik dengan volume sebesar 30 liter. Jerigen plastik yang telah disiapkan, diletakkan diujung saluran inlet sehingga air lindi dapat langsung masuk ke dalam jerigen. Kemudian jerigen air lindi akan disimpan dalam frezer untuk mengawetakan limbah.

Penelitian akan dilakukan di laboratorium air Teknik Lingkungan Universitas Diponegoro. Uji karakteristik awal dan akhir sampel limbah dilakukan untuk mengetahui sifat kimia fisika air. Eksperimen menggunakan alat jar-test konvensional yang dilengkapi dengan 6 beker glass 1 L pada suhu ruangan. Proses pengadukan dilakukan pada dua tahapan yaitu pengadukan cepat $180 \mathrm{rpm}$ selama 2 menit dilanjutkan pengadukan lambat $40 \mathrm{rpm}$ selama 10 menit. Proses pengendapan berlangsung selama satu jam.

Koagulan komersil yang digunakan ialah $\mathrm{Al}_{2}\left(\mathrm{SO}_{4}\right)_{3} .18 \mathrm{H}_{2} \mathrm{O}$ molaritas $666,42 \mathrm{~g} / \mathrm{mol}$ dan $\mathrm{FeCl}_{3}$ diproduksi oleh Merck pro analis. Variasi dosis alummunium sulfat sebesar $12 \mathrm{~g} / \mathrm{L}, 14 \mathrm{~g} / \mathrm{L}, 16 \mathrm{~g} / \mathrm{L}, 18$ $\mathrm{g} / \mathrm{L}$. Variasi $\mathrm{FeCl}_{3}$ yang dihunakan ialah $12 \mathrm{~g} / \mathrm{L}, 14$ $\mathrm{g} / \mathrm{L}, 16 \mathrm{~g} / \mathrm{L}, 18 \mathrm{gr} / \mathrm{l}$. Sedangkan variasi dosis $\mathrm{FeCl}_{3}$ masing-masing sampel yakni $4 \mathrm{~g} / \mathrm{L}, 8 \mathrm{~g} / \mathrm{L}, 12 \mathrm{~g} / \mathrm{L}$, dan $16 \mathrm{~g} / \mathrm{L}$. Percobaan pendahuluan menunjukkan pada dosis di atas $16 \mathrm{~g} / \mathrm{L}$ terjadi penurunan efisiensi penyisihan pengendapan.

Pada uji pendahuluan didapatkan rentang yung baik di antara nilai tersebut, di mana pada penambahan $20 \mathrm{~g} / \mathrm{L}$ terjadi pembetukan buih yang luar biasa alummunium sulfat sehingga mempengaruhi proses. Beberapa fisik kimia parameter yang diuji meliputi TSS, BOD dan COD secara duplo. Pengujian BOD, COD, pH menggunakan metode dalam buku Standard Methods for the Examination of Water and Waste Water 5220C (Clesceri dkk., 1999).

Lindi hasil koagulasi flokulasi yang telah diendapkan kemudian dipisahkan airnya ke gelas beker yang lebih kecil agar lebih mudah diamati dan dilakukan pengujian karakteristik. Hal ini juga bertujuan untuk mencegah tercampur kembali antara 
endapan dan hasil koagulasi karena pergerakan saat pengambilan sampel.

\section{Hasil dan Pembahasan}

\subsection{Karakteristik Air Lindi}

Air lindi yang dihasilkan oleh TPA Jatibarang dikategorikan sebagai lindi tua karena telah berusia lebih dari 10 tahun (IPAL berdiri sekitar akhir tahun 1990-an atau awal 2000). Karakteristik air lindi IPL TPA Jatibarang diuji di Laboratorium Teknik Lingkungan dengan menggunakan peralatan dan prosedur yang sesuai dengan SNI. Beberapa parameter yang diuji yakni suhu, pH, COD, BOD, kekeruhan, TSS dan warna dengan hasil seperti pada Tabel 1.

Tabel 1. Perbandingan Karakteristik Awal Lindi dengan Baku Mutu

\begin{tabular}{lllll}
\hline No & Parameter & Satuan & Hasil & $\begin{array}{l}\text { Baku } \\
\text { Mutu* }\end{array}$ \\
\hline 1. & BOD5 & $\mathrm{mg} / \mathrm{L}$ & 1600 & 50 \\
2. & COD & $\mathrm{mg} / \mathrm{L}$ & 4000 & 100 \\
3. & Kekeruhan & $\mathrm{NTU}$ & 300,0 & \\
4. & TSS & $\mathrm{mg} / \mathrm{L}$ & 522,0 & 100 \\
5. & Warna & $\mathrm{PtCo}$ & 1600,4 & 15 \\
6. & $\mathrm{pH}$ & & 8,5 & $6-9$ \\
7. & Suhu & ${ }^{\circ} \mathrm{C}$ & 28,7 & - \\
*) Menurut Permen LH No. 5 & Tahun 2014 tentang Baku \\
Mutu Air Limbah & \multicolumn{4}{l}{}
\end{tabular}

Semua parameter air lindi pada tabel 1 berada di atas baku mutu. Nilai $\mathrm{BOD}_{5}$ dan $\mathrm{COD}$ sebesar $1626,5 \mathrm{mg} / \mathrm{L}$ dan $3844,3 \mathrm{mg} / \mathrm{L}$, jauh di atas baku mutu air limbah sebesar $150 \mathrm{mg} / \mathrm{L}$ dan $300 \mathrm{mg} / \mathrm{L}$. Rasio BOD/COD lindi TPA sebesar 0,422 menunjukkan limbah cukup sulit terdegradasi. Namun nilai rasio BOD/COD ini cukup tinggi dibandingkan penelitian Rezagama (2012) pada TPA Sarimukti Bandung yang hanya mencapai 0,15 . Pada rasio BOD/COD antara 0,1 hingga 0,5 , stabilitas air lindi dapat digolongkan menjadi "moderately stable" (ElFadel \& Bou-Zeid, 2002). Sedangkan penggolongan TPA berdasarkan umur oleh menyebutkan bahwa TPA Jatibarang termasuk dalam kategori muda (Tchobanoglous, 2002).

Nilai TSS air lindi TPA Jatibarang sebesar 522 $\mathrm{mg} / \mathrm{L}$, dimana baku mutu sebesar $100 \mathrm{mg} / \mathrm{L}$. Nilai warna sebesar 1600,4 PtCo sedangkan baku mutu warna sebesar 15 . Nilai $\mathrm{pH}$ dan temperatur berturut turut sebesar 8,44 dan $28,7{ }^{\circ} \mathrm{C}$, dimana nilai tersebut sudah memenuhi nilai baku mutu $\mathrm{pH}$ dan temperatur sebesar 6-9 dan $40{ }^{\circ} \mathrm{C}$. Parameter $\mathrm{pH}$ juga menandakan sifat agresif lindi dan kondisi aerob dibandingkan anaerob dalam sampah.

COD (Chemical Oxygen Demand) yang terdapat dalam lindi TPA Jatibarang menandakan total oksigen yang dibutuhkan untuk mendegradasi senyawa-senyawa organik. Nilai COD tinggi mengindikasikan semakin besar tingkat pencemaran air yang terjadi oleh bahan-bahan organik. Jika di bandingkan dengan kualitas air lindi Rezagama (2012) pada TPA sarimukti serta penelitian Astuti (2008) pada TPA Putri Cempo Surakarta, terdapat rentang nilai $\mathrm{pH}, \mathrm{COD}$ dan BOD, TSS. Hal ini kemungkinan karena karakteristik sampah organik masyarakat indonesia yang cenderung sama serta situasi sekitar seperti curah hujan, kelembaban, suhu yang relatif hampir mirip.

\subsection{Pengolahan menggunakan koagulan $\mathrm{FeCl}_{3}$}

Penyisihan bahan organik lindi melalui koagulasi flokulasi diasosiasikan dengan mekanisme penyisihan substansi humic. Pada air yang mengandung bahan organik, terdapat hubungan stokiometri antara bahan organik dengan dosis koagulan (Ntampou dkk., 2006). Terdapat dua mekanisme meliputi: a). pengikatan kationik bahan metal dengan bagian anion menghasilkan netralisasi bahan humic dan reduksi kelarutannya; b). Adsorbsi bahan organik ole endapan metal hidroxside amorphous (Duan \& Gregory, 2003). Penampakan mekanisme ini sangat bergantung pada $\mathrm{pH}$. Pada $\mathrm{pH}$ 5-6 substansi humic bermuatan negatif di mana Al dan $\mathrm{Fe}$ hidroksida bermuatan positif sehingga terjadi adsorspsi kuat dan netralisasi.

Tingginya nilai COD pada lindi TPA Jatibarang disebabkan adanya zat organik dari proses dekomposisi tumpukan sampah. Nilai COD diperoleh dari rata-rata pengujian sampel COD secara duplo. Koagulan $\mathrm{FeCl}_{3}$ mampu menurunkan konsentrasi COD paling tinggi pada dosis 16 gram/L mencapai $51 \%$. Jika dosis ini ditambahakna proses akan timbul buih yang sulit dikontrol sehingga menjadi pembatas variasi dosis. Pada penelitian lain, proses koagulasi flokulasi dengan $\mathrm{FeCl}_{3}$ dipengaruhi kuat oleh $\mathrm{pH}$. Ketika kondisi normal basa hanya menyisihkan $16 \%$ COD, namun pada kondisi optimum $\mathrm{pH} 5,5$ penurunan SS, Kekeruhan dan COD mencapai 89\%, 93\%, dan 65\% (Li dkk., 2010). Hal ini dikarenakan fenomena perbedaan spesies terhidrolisis pada kondisi umum oleh ferric $\left(\mathrm{Fe}^{3+}\right)$ dapat bereaksi dengan hydroxyl $\left(\mathrm{OH}^{-}\right)$menghasilkan $\mathrm{Fe}(\mathrm{OH})_{3}$ atau $\mathrm{Fe}(\mathrm{OH})_{4}$ seperti ditunjukkan pada persamaan 1 dan 2. Pada kondisi asam, ferric akan menghidrolisis membentuk polynuclear cation seperti persamaan 3 . $\mathrm{Fex}(\mathrm{OH}) \mathrm{y}^{(3 \mathrm{x}-\mathrm{y})}$ dapat berbentuk $\mathrm{Fe}(\mathrm{OH})^{2+}$, $\mathrm{Fe}_{2}(\mathrm{OH})_{2}^{4+}, \mathrm{Fe}_{3}(\mathrm{OH})_{42}^{5+}$ dan spesies lain bermuatan positif (Ching dkk., 1994).

$$
\begin{aligned}
& \mathrm{Fe}^{3+}+3 \mathrm{OH}^{-}=\mathrm{Fe}(\mathrm{OH})_{3} \quad \ldots \ldots \ldots \ldots \ldots . .(1) \\
& \mathrm{Fe}^{3+}+4 \mathrm{OH}^{-}=\mathrm{Fe}(\mathrm{OH})_{4}^{-} \ldots \ldots \ldots \ldots \ldots \ldots .(2) \\
& x \mathrm{Fe}^{3+}+y \mathrm{H}_{2} \mathrm{O}=\mathrm{Fe} e_{x}(\mathrm{OH})_{y}^{3 x-y}+y H^{+} \ldots(3)
\end{aligned}
$$

Sedangkan pada penyisihan bahan organik dengan $\mathrm{FeCl}_{3}$ pada dosis $1 \mathrm{mg} \mathrm{FeCl} / \mathrm{mg}$ sebesar COD dan $\alpha 254$ sebesar $66 \%$ and $88 \%$ (Oloibiri dkk., 2014). Pengolahan optimal lindi menggunakan dosis $\mathrm{FeCl}_{3} 6 \mathrm{H}_{2} \mathrm{O}$ sebesar $300 \mathrm{mg} / \mathrm{L}$ pada $\mathrm{pH} 3$ dapat menyisihkan $81.9 \%$ Total Carbon, $17.8 \%$ COD, $36.1 \% \mathrm{NH}^{4+}, 27.5 \% \mathrm{~Pb}, 7.7 \% \mathrm{As}$, and $0.3 \% \mathrm{Hg}$. Penyisihan Total Carbon yang tinggi menandakan 
adanya penyisihan asam humic secara signifikan (Vedrenne dkk., 2012).

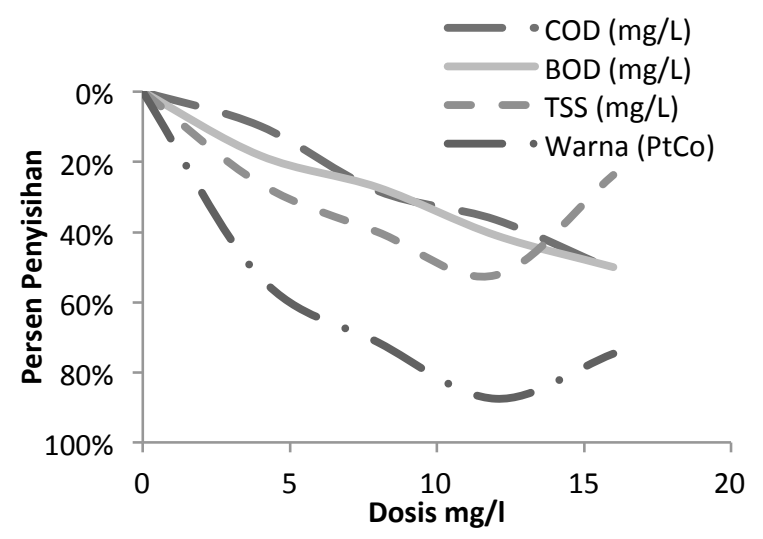

Gambar 1. Grafik Penyisihan COD, BOD, TSS, warna koagulan $\mathrm{FeCl}_{3}$

Pada penelitian lainnya tanpa pengkondisian $\mathrm{pH} 8.3$, penggunaan dosis koagulan $0,2-0,5 \mathrm{Fe}^{3+} / \mathrm{L}$ hanya dapat mereduksi COD antara $9,5 \%$ dan $11 \%$. Jika $\mathrm{pH}$ diatur menjadi 3,8, maka penurunan COD menjadi 26\% dan kekeruhan mencapai 90\%.(Marañón et al. 2008). Penelitian lain menunjukkan kondisi optimal $\left(\mathrm{pH}=7\right.$ dan $\left.1500 \mathrm{mg} / \mathrm{L} \quad \mathrm{FeCl}_{3}\right)$ terjadi penurunan COD, warna dan TSS sebesar 65\%,79\% dan 95\% (Moradi \& Ghanbari, 2014).

Hasil pengamatan menunjukkan bahwa jumlah endapan semakin berkurang dengan penambahan dosis. Pada dosis $16 \mathrm{mg} / \mathrm{L}$ tinggi endapan lebih rendah daripada $12 \mathrm{mg} / \mathrm{L}$. Hal ini disebabkan pada dosis berlebih muatan positif koloid saling menolak satu sama lainnya sehingga mengakibatkan koloid tidak dapat mengendap (Li dkk., 2010).

Total Suspended Solid atau total padatan tersuspensi adalah padatan yang tersuspensi di dalam air berupa bahan-bahan organik dan anorganik yang dapat disaring dengan kertas milipore berpori-pori $0,45 \mu \mathrm{m}$. Materi yang tersuspensi mempunyai dampak buruk terhadap kualitas air karena membatasi penetrasi matahari ke badan air. Pada dosis $\mathrm{FeCl}_{3} 12$ $\mathrm{g} / \mathrm{L}$ TSS memiliki nilai efisiensi penyisihan yang paling besar mencapai $52 \%$ dibandingkan dosis lainnya.

Warna pada air lindi merupakan parameter penting dalam proses pengolahan. Penampakan visual air lindi TPA Sarimukti nampak hitam pekat. Hal ini mengindikasikan adanya kandungan bahan organik alami yang sangat tinggi terutama Asam Humad, Asam Fulvic dan Humid (Zularisam dkk., 2006). Perubahan warna setelah proses ozonasi menjadi kuning cerah menunjukkan terjadinya pemutusan ikatan pada Asam Humad dan Humid yang memudarkan warna kehitaman. Air lindi yang berwarna kuning berasal dari Asam Fulvic. Beberapa penyebab warna merupakan ikatan rangkap yang lebih mudah diputus dengan ozon (TDX 1999). Penyisihan warna dengan koagulan $\mathrm{FeCl}_{3}$ terbaik mencapai $88 \%$ pada dosis 12 gram.

\subsection{Pengolahan menggunakan Koagulan $\mathrm{Al}_{2} \mathrm{SO}_{4}$}

Pada saat dilakukan jar test, terbentuk buih yang cukup tinggi. Ketinggian buih meningkat seiring bertambahnya dosis koagulan yang dibubuhkan. Buih ini sangat mengganggu proses koagulasi di mana pada jumlah yang berlebihan buih akan meluap dari gelas beker.

Selain itu, nampak terbentuk mikroflok yang perlahan berubah menjadi makroflok dan saat pengadukan dihentikan, flok yang terbentuk perlahan mengendap karena adanya gaya gravitasi. Setelah mengendap, buih yang terbentuk mulai berkurang dan lindi bagian atas mulai berubah menjadi jernih. Gambar 2 dan Gambar 3 menunjukkan keadaan setelah pasca pengendapan 30 menit.

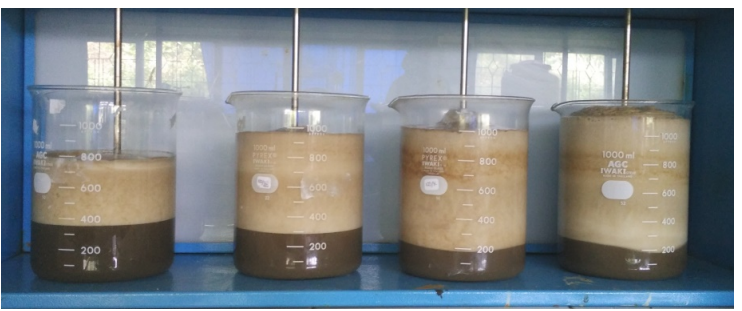

Gambar 2. Munculnya Buih pada Proses Koagulasiflokulasi

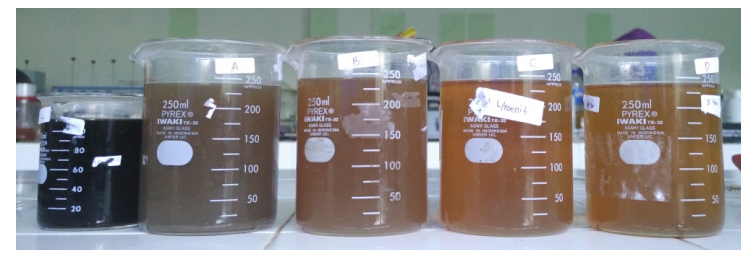

Gambar 3. Lindi Awal dan Hasil Koagulasi-Flokulasi

Air lindi awalnya berwarna hitam pekat, setelah dikoagulasi-flokulasi akan mengalami perubahan warna menjadi coklat kekuning-kuningan. Sementara endapannya berwarna coklat keabu-abuan. Semakin meningkat dosis koagulan yang ditambahkan maka warna pun semakin cerah.

Semakin besar dosis koagulan alumunium sulfat yang dibubuhkan, maka parameter $\mathrm{pH}$, BOD, COD akan mengalami penurunan (Gambar 4). Pada dosis alumunium sulfat $18 \mathrm{~g} / \mathrm{L}$ di dapatkan nilai efisiensi penyisihan yang paling besar COD,TSS mencapai $65 \%$ dan $25 \%$ dibandingkan dosis lainnya. Sedangkan penyisihan BOD nampak lebih signifikan mencapai $62 \%$ pada dosis $18 \mathrm{mg} / \mathrm{L}$. Namun nilai ini berbeda pada tren TSS di mana pada penambahan dosis 12 dan $14 \mathrm{mg} / \mathrm{L}$ terjadi penyisihan negatif. Hal ini dimungkinkan karena pada saat pengambilan sampel terjadi penggumpalan flok lindi yang belum mengendap sehingga terukur di TSSnya menjadi naik. Semakin banyak koagulan yang ditambahkan mengakibatkan penurunan flok yang semakin cepat. 
Teknik, 37 (2), 2016, 82

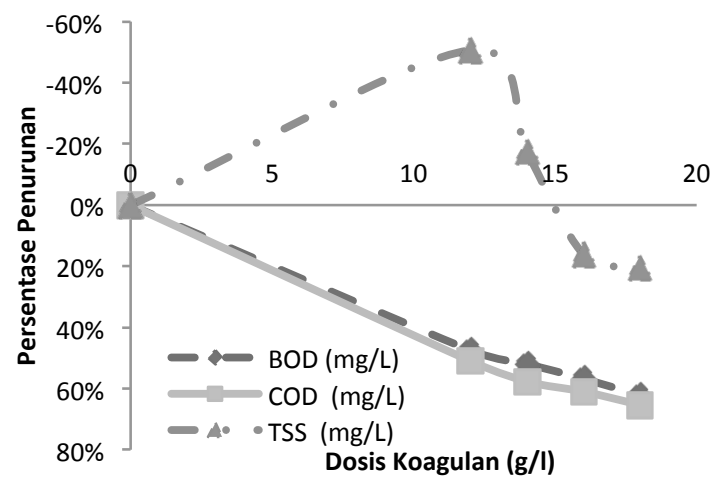

Gambar 4. Grafik Penyisihan BOD, COD dan TSS Koagulan $\mathrm{Al}_{2} \mathrm{SO}_{4}$

Penelitian lain menunjukkan proses optimum $\mathrm{Al}_{2} \mathrm{SO}_{4}$ untuk lindi berada pada $\mathrm{pH} 6$ dengan penyisihan COD sebesar 68\%. Tipe spesies dari $\mathrm{Al}_{2}\left(\mathrm{SO}_{4}\right)_{3}$ terhidrolisi menjadi $\mathrm{Al}^{3+}$ and $\mathrm{Al}(\mathrm{OH})^{2+}$. Penambahan $\mathrm{pH}$ memngakibatkan produk garam almunium terhidrolisis bergeser dari spesies bermuatan lebih positif ke muatan positif yang lebih rendah. Jika dibandingkan dengan $\mathrm{FeCL}_{3}$ maka rentang optimal $\mathrm{pH}$ tidak berbedah jauh (Luan dkk., 1997). Dosis Optimal dari $\mathrm{AL}_{2}\left(\mathrm{SO}_{4}\right)_{3}$ sebesar 100 $\mathrm{mg} / \mathrm{L}$ (setara $9 \mathrm{mg} / \mathrm{L}$ alumunium) pada rentang $\mathrm{pH}$ 7,5 $-8,5$ dapat menurunkan kekeruhan dan TOC mencapai $10 \%$ and $65 \%$, secara langsung (Mariam \& Nghiem, 2010).

Jika dibandingkan antara koagulan kimia, penggunaan $\mathrm{Al}_{2} \mathrm{SO}_{4}$ nampak lebih efisien dengan hasil efisiensi penyisihan yang lebih baik (Gambar 5). Untuk itu sebagian besar PDAM lebih memilih menggunakan $\mathrm{FeCl}_{3}$.

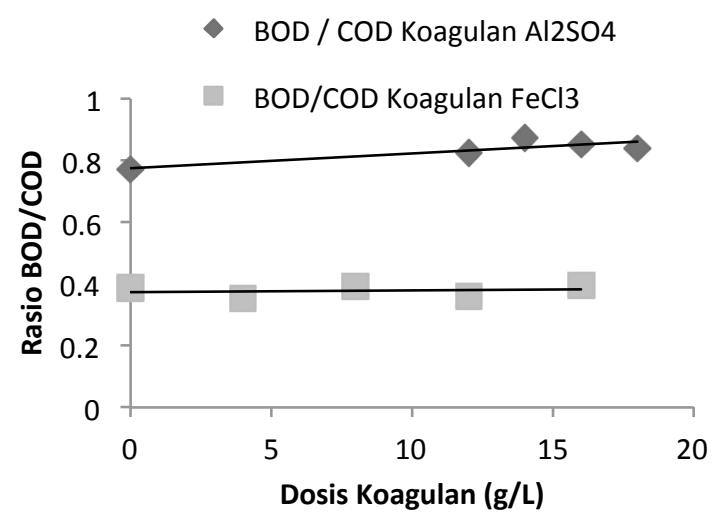

Gambar 5. Rasio BOD/COD hasil pengolahan koagulan $\mathrm{Al}_{2} \mathrm{SO}_{4}$ dan $\mathrm{FeCl}_{3}$

BOD (Biologycal Oxygen Demand) atau jumlah oksigen yang dibutuhkan oleh bakteri untuk menguraikan (mengoksidasi) zat organik yang terlarut dan sebagian zat-zat organik yang tersuspensi dalam air. Tujuan penyisihan nilai BOD pada lindi TPA Jatibarang adalah untuk mengurangi kandungan organik yang ada pada lindi yang dapat diuraikan secara biologi.
Rasio BOD/COD pada pengolahan koagulasi meningkat walaupun tidak secara signifikan. Terjadi perbedaan nilai awal dari lindi yang cukup besar di mana pada $\mathrm{FeCl}_{3}$ rasio cukup rendah sebesar 0,4 sedangkan $\mathrm{Al}_{2} \mathrm{SO}_{4}$ cukup tinggi mencapai 0,78 . Hal ini kemungkinan di pengaruhi oleh kondisi lingkungan saat dilakukan pengambilan lindi.

Proses koagulasi dan flokulasi pada kedua koagulan kimia tersebut menurunkan nilai $\mathrm{pH}$ (Gambar 6). Pada dosis $18 \mathrm{~g} / \mathrm{L}$, terjadi penurunan $\mathrm{pH}$ hingga di bawah baku mutu air buangan. Semakin asam maka proses akan semakin capat dan efisien. Pada penelitian lainnya tanpa pengkondisian $\mathrm{pH}$ penggunaan dosis koagulan $0,32-0,6 \mathrm{AL}^{3+} / \mathrm{L}$ hanya dapat mereduksi COD antara 11,5\% dan 15\%. Jika pH diatur menjadi 3,8, maka penurunan COD menjadi 27\% dan kekeruhan mencapai 90\%.(Marañón dkk., 2008) Substansi Humic setelah diolah dengan koagulasi dapat turun lebih dari 70\% (Poznyak dkk., 2008). Koagulasi dengan $7,5 \mathrm{mM} \mathrm{Al}^{3+}$ menghasilkan penurunan solid dan warna sebesar. $80 \%$ and $93 \%$ dengan diikuti reduksi $30 \%$ chemical oxygen demand (COD) dari nilai awal COD sebesar $3500 \mathrm{mg} / \mathrm{L}$ (Mavros dkk., 2008).

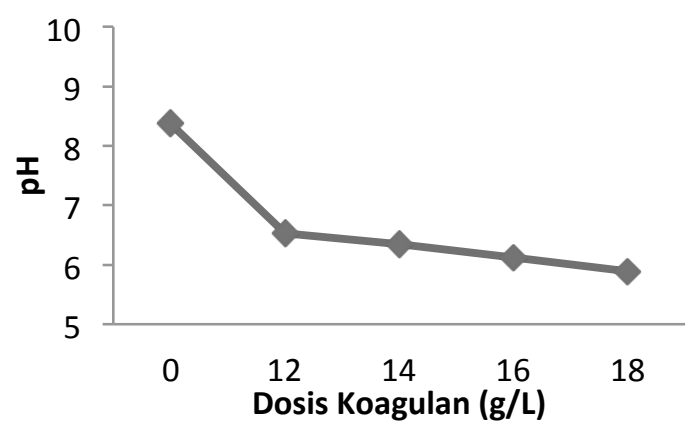

Gambar 6. Grafik Nilai pH Hasil Koagulasi-Flokulasi Koagulan $\mathrm{Al}_{2} \mathrm{SO}_{4}$

\section{Kesimpulan}

Karaktersitik air lindi TPA Jatibarang termasuk dalam kategori "moderately stable" dan lindi muda. Penyisihan bahan organik dengan menggunakan kuagulan kimia $\mathrm{FeCl}_{3}$ dan $\mathrm{Al}_{2} \mathrm{SO}_{4}$ menunjukkan nilai yang cukup signifikan untuk parameter COD, BOD, TSS. Penggunaan dosis optimal terjadi pada $16 \mathrm{~g} / \mathrm{L}$ $\mathrm{FeCl}_{3}$ serta $16 \mathrm{~g} / \mathrm{L} \quad \mathrm{Al}_{2} \mathrm{SO}_{4}$ dapat menurunkan nilai COD sebesar $51 \%$ dan $65 \%$, BOD sebesar $50 \%$ dan $562 \%$, dan TSS sebesar $24 \%$ dan 21\%. Perubahan nilai $\mathrm{pH}$ akibat penambahan koagulan berpengaruh positif terhadap tingkat penyisihan, namun memberikan dampak negatif yaitu buih yang cukup banyak. Peningkatan rasion BOD/COD menunjukkan bahwa limbah semakin baik diolah secara biologi. Hal ini menguntungkan bagi sistem pengolahan lindi eksisting TPA Jatibarang. 


\section{Teknik, 37 (2), 2016, 83}

\section{Daftar Pustaka}

Ali, M., 2011. Rembesan Air Lindi (Leachate) Dampak Pada Tanaman Pangan Dan Kesehatan. Surabaya: UPN press.

Ching, H., Tanaka, T. \& Elimelech, M., 1994. dynamics of coagulation of kaolin particles with ferric chloride. Water Research, 28(3): 559-569.

Clesceri, L.S., Greenberg, A.E. \& Eaton, A.D., 1999. Standard Methods for the Examination of Water and Wastewater. Washington, DC 20005-2605: American Public Health Association.

Duan, J., Gregory, J. 2003. Coagulation by hydrolysing metal salts. $A d v$. in Colloid Interface Sci., 100: 475-502..

El-Fadel, M. \& Bou-Zeid, E., 2002. High-strength leachate from municpal solid waste: An SBR treatability study. Beirut, EPCOWM.

Englehardt, J.D. 2006. Options for Managing Municipal Landfill Leachate: Year 1 Development of Iron-Mediated Treatment Processes. Florida: University of Florida .

Luan, Z., Tang, H. \& Yu, C., 1997. Dynamic transformation and stability of hydrolyzed alum and polyaluminium in the coagulation and flocculation processes. Acta Sci. Circums., 17 (3): $321-327$.

Li, W. et al., 2010. Treatment of stabilized landfill leachate by the combined process of coagulation/flocculation and powder activated carbon adsorption. Desalination, 264(1-2): 5662.

Liu, X. et al., 2012. Landfill leachate pretreatment by coagulation-flocculation process using ironbased coagulants: Optimization by response surface methodology. Chemical Engineering Journal, 200-202: 39-51. Available at: http://linkinghub.elsevier.com/retrieve/pii/S138 5894712007231

Marañón, E. et al., 2008. Coagulation-flocculation as a pretreatment process at a landfill leachate nitrification-denitrification plant. Journal of hazardous materials, 156(1-3): 538-44. Available at: http://www.sciencedirect.com/science/article/pi i/S0304389407018390.

Mariam, T. \& Nghiem, L.D., 2010. Landfill leachate treatment using hybrid coagulationnanofiltration processes. Desalination, 250(2): 677-681.

Mavros, M. et al., 2008. Complete treatment of olive pomace leachate by coagulation, activatedcarbon adsorption and electrochemical oxidation. Water Research, 42(12): 28832888
Moradi, M. \& Ghanbari, F., 2014. Application of response surface method for coagulation process in leachate treatment as pretreatment for Fenton process: Biodegradability improvement. Journal of Water Process Engineering, 4(2014): 67-73. Available at: http://linkinghub.elsevier.com/retrieve/pii/S221 4714414000841.

Ntampou, X., Zouboulis, A.I. \& Samaras, P., 2006. Appropriate combination of physico-chemical methods (coagulation/flocculation and ozonation) for the efficient treatment of landfill leachates. Chemosphere, 62(5): 722-30. Available at: http://www.sciencedirect.com/science/article/pi $\mathrm{i} / \mathrm{S} 0045653505006442$.

Oloibiri, V. et al., 2015. A comparative study on the efficiency of ozonation and coagulationflocculation as pretreatment to activated carbon adsorption when treating biologically stabilized landfill leachate. Waste Management, 43(: 335-342. Available at: http://dx.doi.org/10.1016/j.wasman.2015.06.01 4.

Poznyak, T. et al., 2008. Decomposition of toxic pollutants in landfill leachate by ozone after coagulation treatment. Journal of hazardous materials, 152(3): 1108-14. Available at: http://www.sciencedirect.com/science/article/pi $\mathrm{i} / \mathrm{S} 030438940701117 \mathrm{X}$.

Vedrenne, M. et al., 2012. Characterization and detoxification of a mature landfill leachate using a combined coagulationflocculation/photo Fenton treatment. Journal of hazardous materials, 205-206: 208-215. Available at: http://www.ncbi.nlm.nih.gov/pubmed/2224434 3.

Tchobanoglous, G.K.F., 2002. Handbook of Solid Waste Management, 2nd. s.1.:McGraw-Hill.

TDX, 1999. The Ozone. [Online] http://www.tesisenred.net/bitstream/handle/108 03/1520/TOL167B.pdf? sequence $=2$

[Accessed 15 Januari 2012].

Renoua, S. et al., 2005. Landfill Leachate Treatment : Review And Opportunities.

Rezagama, A. \& Notodarmojo, S., 2012. Kinetika Transfer Ozondan Tren Kekeruhan dalam Air Lindi dengan Pengolahan Ozonisasi.

Tjokrokusumo, 1995. Pengantar Engineering Lingkungan. Yogyakarta: STTL YLH.

Zularisam, A., Ismail, A. \& Salim, R., 2006. Behaviours of natural organic matter in membrane filtration for surface water treatment - a review. Desalination, 194(1-3): 211-231. 